\title{
Historical Writing During the Reign of Shah 'Abbas: Ideology, Imitation, and Legitimacy in Safavid Chronicles. Salt Lake City, University of Utah Press, 2000, xiii + 197 p., tables, appendices, index.
}

\section{Colin Mitchell}

\section{(2) OpenEdition}

\section{Journals}

Édition électronique

URL : http://journals.openedition.org/abstractairanica/4628

DOI : $10.4000 /$ abstractairanica.4628

ISSN : 1961-960X

Éditeur :

CNRS (UMR 7528 Mondes iraniens et indiens), Éditions de l'IFRI

Édition imprimée

Date de publication : 15 mai 2004

ISSN : 0240-8910

\section{Référence électronique}

Colin Mitchell, « Historical Writing During the Reign of Shah 'Abbas: Ideology, Imitation, and Legitimacy in Safavid Chronicles. Salt Lake City, University of Utah Press, 2000, xiii + 197 p., tables, appendices, index. », Abstracta Iranica [En ligne], Volume 25 | 2004, document 169, mis en ligne le 15 mars 2006, consulté le 25 septembre 2020. URL : http://journals.openedition.org/abstractairanica/4628 ; DOI https://doi.org/10.4000/abstractairanica.4628

Ce document a été généré automatiquement le 25 septembre 2020.

Tous droits réservés 


\section{Historical Writing During the Reign of Shah 'Abbas: Ideology, Imitation, and Legitimacy in Safavid Chronicles. Salt Lake City, University of Utah Press, 2000, xiii + 197 p., tables, appendices, index.}

\section{Colin Mitchell}

1 Historical Writing During the Reign of Shah 'Abbas by Sholeh Quinn is the first book-length treatment of the complex and multifaceted subject of Safavid historiography. The author points out that an analysis and comparison of Safavid court chronicles would shed valuable light on the various manifestations of Safavid dynastic ideology. Of course the Safavids rank as one of the more malleable ruling families in terms of selflegitimation, cloaking themselves with a variety of genealogies, titulature, and religiopolitical claims. A study promising to make sense of this complex process in the arena of historiography is timely and welcome.

2 The author uses the introduction to contextualize the Safavid dynasty, and the critical concept of historical writing in a Perso-Islamic environment. This, in turn, is followed by a detailed discussion of the various sources comprising Safavid historiography in the 16th and early 17th centuries, and here we note a strong tendency towards categorization. Pre-Safavid 'Model Sources', such as Ibn Bazzaz's Safvat al-safa and Mirkhvand's Rawzat al-safa, are discussed alongside the various Safavid 'Models' of history, namely the early Herati model (Amini's Futuhat-i shahi and Khvandamir's Habib al-siyar), the Qazvini tradition under Shah Tahmasp (including Qazvini's Lubb al-tavarikh and Rumlu's Ahsan al-tavarikh), and later chronicles from the reign of Shah 'Abbas (most notably Qazi Ahmad al-Qummi's Khulasat al-tavarikh, and Iskander Beg Munshi's Tarikh-i 'alam-ara-yi 'Abbasi). The author then examines the role of imitative writing in Safavid 
chronicles, and surveys passages from a number of wide-ranging sources (Tarikh-i Qizilbash, Nuqavat al-asar, Tarikh-i 'Abbasi) to suggest that historians consciously amended or altered passages borrowed from Khvandamir to reflect ongoing shifts and debates in dynastic ideology. In terms of Safavid origins, we are shown that critical passages discussing the life, and specifically the dream episodes, of the eponymous founder of the Safavid Order - Shaikh Safi al-Din - were edited and in some cases falsified to demonstrate the practice of shi'ite rituals and depth of 'Alid convictions by the early Safavid shaikhs. Quinn switches gear subtly in the third section, a focused historical case-study of the rebellion of Ya'qub Khan $\mathrm{Zu}$ al-Qadr in 998/1590, and here we are introduced to the significant conclusion that contemporary bureaucratic reports and orders from the court and field were possibly used by historians like Iskander Beg Munshi when later compiling their majestic court chronicles. Lastly, Quinn offers an overview of Safavid historiographical legacies by comparing a number of Mughal and Safavid historical texts in terms of prefaces (dibachas) and dream episodes, as well as providing a short synopsis of historical writing during the Afsharid period.

Numerous tables and charts are used to compare and demonstrate changes in various critical historical passages, and the author also provides a very useful appendix listing manuscripts and publications that have been discovered and/or published in recent years and which are not discussed in the bibliographical surveys of Charles Storey and Iuri Bregel.

\section{INDEX}

Thèmes : 4.2.1. Safavides et Qâjârs

nompropre Safavides

\section{AUTEURS}

\section{COLIN MITCHELL}

Dalhousie University - Halifax 